however, made any negative comments on this issue; on the contrary, several women commented that they thought this kind of study important. Our investigation was considered and approved by all the concerned research ethics committees.

\section{CONCLUSIONS}

We conclude that most of the participants in this trial had been informed, but in many cases the information did not follow the guidelines of the Declaration of Helsinki. One third of the participants had not been aware that they had the option of withdrawing their participation at any time. There were systematic differences between the various participating clinics in that certain clinics were better at informing their patients than others. Our findings indicate that it is important that the researchers who are responsible for carrying out the project in practice also participate in the design stage of the project. Despite the narrow limits of our investigation certain deficiencies in the informing procedures were indicated, and, despite the ethical dilemmas, it points out the need for further follow up investigations.
1 Faden RR, Beauchamp TL. A history and theory of informed consent. New York: Oxford University Press, 1986

2 World Medical Association. Helsinki Declaration, 1975. In: Beauchamp TL, Walters LW, eds. Contemporary issues in bioethics. 2nd ed. Belmont, California: Wadsworth Publishing Company, 1982.

3 Appelbaum PS, Roth LH. Competency to consent to research. Arch Gen Psychiatry 1982;39:951-8.

4 Stanley B, Guido J, Stanley M, Shortell D. The elderly patient and informed consent. Empirical findings. ЭAMA 1984;252:1302-6.

5 Silva MC, Sorell JM. Enhancing comprehension of information for informed consent: a review of empirical research. IRB. Vol 10. New York: Hastings consent: a review of empiric

6 Simes RJ, Tattersall NHN, Coates AS, Raghavan D, Solomon HJ, Smartt H. Randomised comparison of procedures for obtaining informed consent in

7 Cassileth BR, Zupkis RB, Sutton-Smith K, March V. Informed consent - why are its goals imperfectly realized? N Engl f Med 1980;302:896-900.

8 Taub HA. Informed consent, memory, and age. Gerontologist 1980;20:686-90. 9 Gray BH. Human subjects in medical experimentation: a sociological study of the conduct and regulation of clinical research. New York: Wiley-Interscience, 1975

10 Lynöe N, Jacobsson L. Kvalitet eller integritet-En pilotstudie av en forskningsetisk kommitté. (Quality of research or autonomy of the participants - a pilot study of a research ethics committee.) Lakartidningen 1987;84:3246-8.

11 Weström L. Behandling av akut äggledarinflammation med enbart antibiotika, eller med antibiotika i kombination med anti-inflammatorisk drog. (Treatment of salpingitis acuta with antibiotics solely or in combination with an antiphlogistic drug.) Protocol for the research ethics committees, Diavienomber 201-86, University of Lund, 1986.

(Accepted 3 fune 1991)

\title{
Increased sensitivity of dopamine receptors and recurrence of affective psychosis after childbirth
}

Department of Psychiatry, Institute of Psychiatry, London SE5 8AF

A Wieck, MRCPSYCH, lecturer

R Kumar, FRCPSYCH, reader M N Marks, DPHIL, lecturer S A Checkley, FRCPSYCH, dean

\section{Department of}

Neuroscience, Institute of

Psychiatry, London

SE5 8AF

A D Hirst, BSC, research

worker

I C Campbell, DSC, reader

Correspondence to:

Dr Kumar.

BMF 1991;303:613-6

\author{
A Wieck, R Kumar, A D Hirst, M N Marks, I C Campbell, S A Checkley
}

\author{
Abstract \\ Objective-To test the hypothesis that affective \\ psychosis after childbirth is associated with an \\ altered sensitivity to dopaminergic stimulation.
}

Design-Prospective study of pregnant women at high risk of developing an affective psychosis after childbirth. Clinical assessments in pregnancy and after delivery were made by using a semistructured interview (schedule for affective disorders and schizophrenia) and psychiatric illnesses were categorised according to operational criteria (research diagnostic criteria).

Setting-Obstetric and psychiatric departments in and around Greater London.

Subjects -29 pregnant women with a history of bipolar or schizoaffective psychosis and 47 control pregnant women. Of these, 16 from each group participated in a growth hormone challenge test and the results for 15 women in each group were analysed.

Interventions-On the fourth day postpartum women participating in the hormone challenge test were given a subcutaneous injection of a small dose $(0.005 \mathrm{mg} / \mathrm{kg})$ of the dopamine agonist apomorphine.

Main outcome measures-Growth hormone secretion in response to apomorphine as an index of the functional state of hypothalamic dopamine receptors.

Results - Eight of the 15 women at risk of psychosis subsequently had a recurrence of illness (five bipolar, one schizomanic, and two major depressive illnesses); these women had significantly greater growth hormone responses to apomorphine than the seven at risk women who remained well and the 15 controls, and there were no significant differences between groups in average baseline growth hormone concentrations. The mean (SD) concentrations for women with recurrence, women at risk who remained well, and control women respectively were: average baseline concentrations 1.06 (1.14),
$1.44(1.39)$, and $0.90(1.34) \mathrm{mU} / \mathrm{l}$; peak increase in concentrations $13.68(12.95), 3.46(4.68)$, and 3.40 $(3.83) \mathrm{mU} / 1$ (between group difference $\mathrm{p}<0.05$ ); average increase in concentrations $6.74(7.01), 1.78$ (3.39), and $1.40(2.05) \mathrm{mU} / 1$ ( $\mathrm{p}<0.05)$.

Conclusions-The onset of affective psychosis after childbirth was associated with increased sensitivity of dopamine receptors in the hypothalamus and possibly elsewhere in the brain. Such changes may be triggered by the sharp fall in circulating oestrogen concentrations after delivery.

\section{Introduction}

Childbirth is a potent precipitator of severe mental illness: a woman is about 20 times more likely to require admission to hospital for a psychotic illness in the month after delivery than in any month in the previous two years. ' Women with a history of affective psychosis, related or unrelated to childbirth, are particularly vulnerable, and relapse rates of $50 \%$ have been reported. ${ }^{2}$ Prospective investigations of such women through pregnancy and the postpartum period therefore permit rigorous evaluation of putative aetiological mechanisms.

Of all the endocrine changes taking place after parturition, the sharp fall in circulating sex steroid hormone concentrations is perhaps most likely to contribute to the precipitation of psychosis in predisposed women. Unlike most other hormones steroids have easy access to the brain and concentrations of oestradiol and progesterone in plasma and cerebrospinal fluid are highly correlated. ${ }^{4}$ Recent research has shown that oestrogens modulate the function of monoaminergic and, in particular, dopaminergic neurotransmitter systems in the central nervous system. ${ }^{56}$ Abnormalities of dopaminergic neurotransmission have been implicated in both schizophrenic and manic depressive illness, and Cookson has proposed that puerperal psychosis is triggered by the 
effects of postpartum oestrogen withdrawal on central dopaminergic functions. In clinical investigations the secretion of growth hormone in response to a small dose of the dopamine agonist apomorphine has been used as an index of the responsiveness of dopamine sensitive neurones (probably via $\mathrm{D}_{2}$ receptors) in the hypothalamus or elsewhere in the brain. ${ }^{8} \mathrm{~A}$ major difficulty with these studies lies in finding ill patients who have not recently been treated with psychotropic drugs, which interfere with growth hormone secretion. We have examined the apomorphine induced growth hormone response on the fourth day post partumthat is, before the likely onset of illness--in women at high risk of puerperal affective psychosis to see whether it discriminates between women who subsequently have recurrence of psychosis and those who remain well.

\section{Methods}

Psychiatrists and obstetricians from several centres in and around Greater London referred to us 38 pregnant women who had a history of manic depressive or schizoaffective illness and who agreed to take part in a prospective investigation of psychosocial and biological factors that might be involved in the recurrence of affective psychosis after childbirth. Twenty nine of these women fulfilled the additional selection criteria of having no current psychiatric illness and not taking psychotropic drugs. Forty seven control subjects with no history of psychiatric disorder were recruited at random from the antenatal clinic of King's College Hospital. The aims and procedures of the study were explained and all subjects agreed to take part as unpaid volunteers. Sixteen of the 29 "at risk" mothers and 16 controls participated in the growth hormone test after delivery. The remaining women either did not wish to take part or were excluded because of major obstetric complications which might have altered the test results (for example, caesarean section, surgery under general anaesthesia, blood loss of more than $500 \mathrm{ml}$, or blood transfusions).

All subjects were interviewed at 36 weeks of pregnancy and at six months post partum by using the schedule for affective disorders and schizophrenia. ${ }^{9}$ Interview data were supplemented by information from hospital case notes. Past psychiatric episodes and postnatal relapses were categorised according to the research diagnostic criteria. ${ }^{10}$ The postnatal period was defined as the first 90 days after delivery.

The fourth day after delivery was chosen for the

Characteristics of sample and results of neuroendocrine investigations in women at risk who did or did not develop psychosis after pregnancy and controls

\begin{tabular}{|c|c|c|c|c|}
\hline & $\begin{array}{c}\text { Controls } \\
(\mathbf{n}=15)\end{array}$ & $\begin{array}{l}\text { Women with } \\
\text { recurrence of } \\
\text { psychosis } \\
(n=8)\end{array}$ & $\begin{array}{c}\text { Women at risk } \\
\text { who remained } \\
\text { well } \\
(n=7)\end{array}$ & $\mathrm{p}$ Value \\
\hline Mean (SD) age (years) & $29 \cdot 2(4 \cdot 5)$ & $31 \cdot 6(5 \cdot 5)$ & $32 \cdot 3(5 \cdot 7)$ & $\mathrm{NS}^{\star}$ \\
\hline Mean (SD) weight $(\mathrm{kg})$ & $67 \cdot 3(10 \cdot 3)$ & $69 \cdot 8(7 \cdot 7)$ & $67 \cdot 0(14 \cdot 9)$ & NSt \\
\hline $\begin{array}{l}\text { Median (range) No of months not taking } \\
\text { neuroleptics }\end{array}$ & & $22(4-54)$ & $29(12-110) \ddagger$ & NSS \\
\hline Mean (SD) growth hormone concentrations (mU/l): & & & & \\
\hline Baseline & $0.90(1 \cdot 34)$ & $1.06(1 \cdot 14)$ & $1.44(1 \cdot 39)$ & NS \\
\hline Peak increase after apomorphine & $3.40(3.83)$ & $13.68(12.95)$ & $3 \cdot 46(4 \cdot 68)$ & $<0.059$ \\
\hline Average increase after apomorphine & $1.40(2.05)$ & $6 \cdot 74(7 \cdot 01)$ & $1 \cdot 78(3.39)$ & $<0.05^{\star \star}$ \\
\hline Median (range) mood score & $27(9-52)$ & $42(16-61)$ & $47(11-63)$ & NStt \\
\hline
\end{tabular}

${ }^{\star} F=1.07$, total $\mathrm{df}=29$ (probability of $F$ value, one way analysis of variance)

$\dagger F=0 \cdot 16$, total $\mathrm{df}=29$ (probability of $F$ value, one way analysis of variance)

$\ddagger$ Data missing for one patient.

Mann-Whitney $U$ test, $U=11 \cdot 5, \mathrm{n}=12$

$\| F=0 \cdot 76$, total $\mathrm{df}=29$ (data logarithmically transformed before one way analysis of variance).

q $F=4 \cdot 28$, total $\mathrm{df}=29$ (data logarithmically transformed before one way analysis of variance). Multiple comparisons, least significant difference test: women with recurrence $v$ controls, $\mathrm{p}<0.05$; women with recurrence women who remained well, $\mathrm{p}<0 \cdot 05$.

$\star \star F=4 \cdot 05$, total $\mathrm{df}=29$. Multiple comparisons, least significant differ

$\mathrm{p}<0 \cdot 05$; women with recurrence $v$ women who remained well, NS.

+ No significant difference by Kruskall Wallis test among the three groups $\left(\chi^{2}=4 \cdot 07, n=29\right)$. Women with

recurrence and women who remained well combined $v$ controls by Mann-Whitney $U$ test, $\mathrm{U}=59 \cdot 0, \mathrm{n}=29, \mathrm{p}<0 \cdot 05$. neuroendocrine investigation because, on the one hand, it allowed a period of recovery during which drugs given during labour would be mostly cleared and, on the other hand, because it was expected to fall into the characteristic "lucid interval" before the onset of the acute psychosis. The growth hormone test was carried out according to Corn et al." Women were separated from their babies throughout the test. Between 9 am and 10 am an intravenous cannula was inserted into a forearm vein. After a resting period of one hour $5 \mathrm{ml}$ blood samples were collected every 15 minutes from 30 minutes before to 90 minutes after subcutaneous injection of apomorphine $(0 \cdot 005 \mathrm{mg} / \mathrm{kg})$. The mood state at the start of the test was assessed by using one of a series of visual analogue scales with "happy" as 0 and "sad" as 100 on a $100 \mathrm{~mm}$ scale which the subject completed before the first blood sample was taken.

Plasma growth hormone concentrations were assayed immunoradiometrically by using a proprietary kit (Novo BioLabs, United Kingdom). The growth hormone standards of the kit were calibrated against the international reference preparation $(66 / 217)$. The results of the growth hormone assays were calculated from these standards and are expressed in $\mathrm{mU} / \mathrm{l}$. At growth hormone concentrations of $9 \cdot 0,24 \cdot 0$, and $46 \cdot 0$ $\mathrm{mU} / \mathrm{l}$ intra-assay and interassay coefficients of variation were $6 \cdot 5 \%, 7 \cdot 1 \%$, and $5 \cdot 5 \%$ and $9 \cdot 4 \%, 8 \cdot 5 \%$, and $9 \cdot 6 \%$, respectively.

\section{Results}

The 16 women at risk of recurrence of affective psychosis who participated in the growth hormone challenge test did not differ significantly from the other 13 women at risk with respect to mean (SD) age $(32.4$ $(5.7)$ years $v 31.9(3.5)$ years), social class (proportion of manual workers $4 / 16(25 \%) v 6 / 13(46 \%))$, numbers of previous psychiatric admissions (median in both groups $=1)$, and rates of relapse after this delivery $(9 / 16$ $(56 \%) v 6 / 13(46 \%))$. Within the control group the participants and non-participants in the test also did not differ significantly in regard to mean age $(28 \cdot 7(4 \cdot 3)$ $v 31 \cdot 1(4 \cdot 7)$ years) and proportion of manual workers $(9 / 16(56 \%) v 18 / 31(58 \%))$. One at risk woman did not complete the test and one control was excluded from data analysis because her baseline growth hormone concentration was above $6 \mathrm{mU} / \mathrm{l}$; this cut off point was used to avoid the negative feedback effect of growth hormone on its own secretion. ${ }^{12}$

Of the 15 women at risk who completed the test, 13 had a history of bipolar manic depressive illness, one of schizoaffective mania, and one of schizoaffective depression. No woman had a psychiatric illness according to the research diagnostic criteria during the two months before delivery. Eight of the at risk women had recurrence of illness-five had episodes of mania with or without depression, one had schizomania, and two had major depression. Only two of the women had a recurrence later than the end of the first week, and four women were showing some emotional lability at the time of the growth hormone test (three women were slightly disinhibited and overtalkative and one woman was tearful). None of the control mothers became ill.

The table summarises the characteristics of the sample and the results of the growth hormone test for the controls $(n=15)$, the patients with recurrence of psychosis $(n=8)$, and the women at risk of psychosis who remained well $(n=7)$. The figure shows the individual growth hormone response curves for all subjects in each group. There were no significant differences between groups with respect to age and body weight nor between the two subgroups of women at risk of psychosis in the time since they had last been 

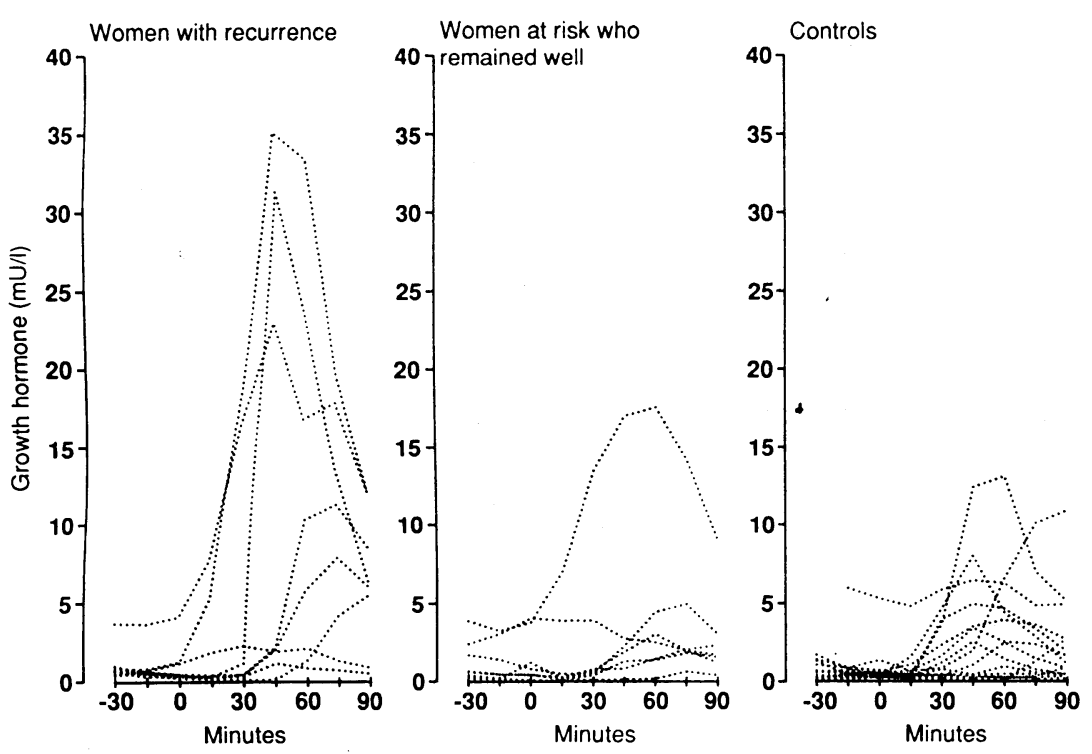

Growth hormone responses to apomorphine on fourth day after delivery in eight women at risk of puerperal affective psychosis who had recurrence, in seven at risk who remained well, and in 15 controls. (Apomorphine hydrochloride $(0.005 \mathrm{mg} / \mathrm{kg}$ ) was given by subcutaneous injection at time 0 )

treated with neuroleptic drugs. No woman had received any psychotropic drug for at least two months before the test except for antiemetics and opiates given around the time of labour and delivery to one woman who had a recurrence (pethidine $100 \mathrm{mg}$ intramuscularly and prochlorperazine $12.5 \mathrm{mg}$ intramuscularly), three at risk women who remained well (pethidine $100 \mathrm{mg}$, and prochlorperazine $12.5 \mathrm{mg}$ in one) and seven control mothers (six received pethidine $100 \mathrm{mg}$ and prochlorperazine $12.5 \mathrm{mg}$, and one dextropropoxyphene 65 $\mathrm{mg}$ ). The proportion of women being given opiates or antiemetics was not significantly different among the three groups $\left(\chi^{2}=2 \cdot 77, \mathrm{df}=2\right.$ and $\left.\chi^{2}=2 \cdot 73, \mathrm{df}=2\right)$. One woman, who later had a recurrence of illness, was given temazepam for the first three nights post partum.

The average baseline growth hormone concentrations were similar in the three groups. The area under the growth hormone response curve was calculated by subtracting the average baseline concentration from the average concentration after the administration of apomorphine. Average baseline concentrations were also subtracted from the absolute peak values to obtain peak increases. Because the variance of increases in peak and average growth hormone concentrations was significantly different among the three groups the data were transformed logarithmically before all statistical tests. The women who had recurrence of psychosis had significantly greater growth hormone responses (peak increases and average increases) to apomorphine than those at risk who remained well and their peak increases were also significantly greater than those of the controls. Of the two women who experienced a recurrence of major depression, one had an increased growth hormone response and one did not. There was no difference in the growth hormone responses between the at risk women who remained well and the controls.

Within the group of women with a recurrence the four who seemed to have mild prodromal symptoms at the time of the test did not differ in their growth hormone responses from the other four women (mean (SD) peak increase 13.58 (11.71) and 13.76 (15.95) $\mathrm{mU} / \mathrm{l}, t=-0 \cdot 50, \mathrm{df}=6$, not significant; average increase $5.42(4.71)$ and $8.08(9.37) \mathrm{mU} / 1, t=0.00, \mathrm{df}=6$, not significant). The 15 at risk women taken together rated themselves on the mood scale as less happy than the controls, but the mood scores of those with subsequent recurrence were not different from those who remained well. Mood ratings did not correlate with the growth hormone responses (Pearson's correlation coefficient $r=0 \cdot 05, \mathrm{n}=29$ for peak increase in growth hormone and $r=0 \cdot 08, \mathrm{n}=29$ for average increase, both not significant). Subjects were also split into two groups according to median mood score $(33.69 \mathrm{~mm}$, $\mathrm{n}=29$ ), and there was no significant difference in peak growth hormone response $(t=-0 \cdot 18, \mathrm{df}=27)$ and average growth hormone increase $(t=-0 \cdot 19, \mathrm{df}=27)$ between the two groups. It seems unlikely, therefore, that the enhanced growth hormone responses in women with recurrence of psychosis were a reflection of affective or behavioural changes at the time of the test.

Twelve at risk women had been treated with neuroleptic drugs in the past (7/8 women with recurrence and 5/7 who remained well, data on one subject who remained well were not available). The length of time that these women had stopped taking neuroleptic drugs did not correlate with their growth hormone responses (Pearson's correlation coefficient $r=-0 \cdot 33$, $\mathrm{n}=12$ for peak increase in growth hormone concentration and $r=-0 \cdot 36, \mathrm{n}=12$ for average increase, both not significant), and there was also no difference between subjects if they were split into two groups according to median time not taking neuroleptics (median $=27$ months, $t=1 \cdot 24, \mathrm{df}=10$ for peak increase, and $t=1 \cdot 21, \mathrm{df}=10$ for average increase, both not significant). Antiemetic or opiate drugs given during labour and delivery had no effect on growth hormone responses either within the control group (for antiemetics $t=0.33, \mathrm{df}=13$ for peak increase and $t=0.13$, $\mathrm{df}=13$ for average increase; for opiates $t=-0.02$, $\mathrm{df}=13$ and $t=-0 \cdot 26, \mathrm{df}=13$, not significant) or when the responses of control and at risk subjects were analysed together $(t=0.36, \mathrm{df}=28, t=0.05, \mathrm{df}=13$ and $t=0.58, \mathrm{df}=28, t=-0.78, \mathrm{df}=28$, not significant, respectively).

\section{Discussion}

The growth hormone response to the dopamine agonist apomorphine was enhanced on the fourth day after delivery in women who were about to have a recurrence of affective psychosis. The significance of the presence of mild prodromal symptoms in half of these subjects is uncertain and in future studies tests at different times after delivery are needed. Previous neuroendocrine investigations of dopaminergic function in affective illnesses have yielded conflicting results and may have been influenced by confounding factors such as incomplete withdrawal from drugs, weight loss, and other non-specific effects of a severe mental illness. ${ }^{13}$ The strategy of investigating high risk subjects just before they are likely to become severely ill avoids these problems. However, some other variables which could have confounded our results need to be considered.

In the prodromal phase of puerperal psychosis women often have appreciable insomnia. We did not measure this, but if some of the subjects with a subsequent recurrence of psychosis had less sleep before the test this would have reduced rather than enhanced the growth hormone response to apomorphine. ${ }^{14}$ Breast feeding was not permitted during the test, and breast feeding before the test could also not have accounted for differences in endocrine responsiveness: only two at risk subjects did not attempt to breast feed-one relapsed and one did not. Within the control group there were no differences in mean (SD) growth hormone concentrations between the nine breast feeding women and the six bottle feeding women (baseline $0.64(0.32)$ and $1.26(2 \cdot 15) \mathrm{mU} / \mathrm{l}, t=$ $-0.38, \mathrm{df}=13$; peak increase $4.00(4.30)$ and 2.54 (3.14) $\mathrm{mU} / \mathrm{l}, t=0.78, \mathrm{df}=13$; average increase 1.60 $(2 \cdot 32)$ and $1 \cdot 10(1 \cdot 71) \mathrm{mU} / \mathrm{l}, t=0 \cdot 34, \mathrm{df}=13$; all comparisons were not significantly different). 
Apomorphine is thought to increase growth hormone secretion by stimulating postsynaptic dopamine receptors, probably of the $\mathrm{D}_{2}$ type, in the median eminence of the hypothalamus. ${ }^{15}$ There is evidence that the sensitivity of these receptors or of some associated intracellular mechanism is influenced by female sex steroid hormones. Thus the growth hormone response to apomorphine is enhanced in women taking oral contraceptives ${ }^{16}$ and, in women with spontaneous cycles, it is much greater in the mid-luteal than the early follicular phase of the menstrual cycle. ${ }^{17}$ Variations in sex steroid concentrations do not influence growth hormone secretion induced by growth hormone releasing hormone, ${ }^{18} 19$ and this indicates that they act at a suprapituitary level. In animal studies oestrogens have been shown to have pronounced effects on the function of central dopaminergic neurotransmitter systems. Several sites of action have been identified, including those of dopamine synthesis ${ }^{20}$ and postsynaptic receptor function. ${ }^{21}$ Recently, oestrogenic effects have been shown at a molecular level; thus Blum et al reported a considerable decrease, after oestrogen treatment, in the transcription of the gene for tyrosine hydroxylase, the rate limiting enzyme for dopamine synthesis. ${ }^{22}$

We do not know how the dopaminergic system is functioning in normal or high risk women just before delivery. Thus it is not possible to explain how the enhanced response to dopaminergic stimulation may have arisen in the women with recurrence of psychosis after childbirth. Investigating the same subjects after recovery across the menstrual cycle may help to elucidate how dopaminergic function alters with a varying hormonal milieu. The possible link between oestrogen "withdrawal," increased sensitivity to dopaminergic stimulation, and puerperal affective psychosis is intriguing and may hold the key for successful prevention of recurrent psychoses. We are currently investigating whether oestrogen given to high risk women soon after delivery will reduce rates of recurrence, as was originally described by Hamilton in an uncontrolled series of 40 subjects, ${ }^{23}$ and whether it will normalise dopamine receptor function.

This study was funded by the Medical Research Council, the Health Promotion Research Trust, and the Gatsby Trust. We thank our many colleagues for referring suitable subjects for this research and all the mothers who helped us to carry it out. We also thank Brian Everitt, professor of statistics in behavioural science at the Institute of Psychiatry, London, for statistical advice.

1 Kendell RE, Chalmers JC, Platz C. Epidemiology of puerperal psychosis $B r f$ Psychiatry 1987;150:662-73

2 Dean C, Williams RJ, Brockington IF. Is puerperal psychosis the same as bipolar manic-depressive disorder? A family study. Psychol Med 1989;19. 637-47

3 Kumar R, Isaacs S, Meltzer E. Recurrent post-partum psychosis Brf Psychiatry 1983;142:618-20

4 Backstrom T, Carstensen H, Sodergard R. Concentration of estradiol, testosterone and progesterone in cerebrospinal fluid compared to plasm unbound and total concentrations. F Steroid Biochem 1976;7:469-72.

5 Deakin JFW. Relevance of hormone-CNS interactions to psychological changes in the puerperium. In: Kumar R, Brockington IF, eds. Motherhood and mentul illness 2. London: Wright, 1988:113-32.

6 Wieck A. Endocrine aspects of postnatal mental disorders. In: Oates $M$, ed. Psychological aspects of obstetrics and gynaecology. Baillière's clinical obstetrics and gynaecology. Vol 3/4. London: Baillière Tindall, 1989:857-77.

7 Cookson JC. The neuroendocrinology of mania. $\mathcal{F}$ Affective Disord 1985;8: 233-41.

8 Matussek N. Catecholamines and mood: neuroendocrine aspects. Current topics in neuroendocrinology. Vol 8. Berlin: Springer, 1988:141-82.

9 Endicott J. Spitzer RL. A diagnostic interview. Arch Gen Psychiatry 1978;35: $837-44$

10 Spitzer RL, Endicott J, Robins E. Research diagnostic criteria. Rationale and reliability. Arch Gen Psychiatry 1978;35:773-82.

11 Corn T, Hale AS, Thompson C, Bridges PK, Checkley SA. A comparison of the $\mathrm{GH}$ responses to clonidine and apomorphine in the same endogenousl depressed patients. Br $\mathcal{F}$ Psychiatry 1984;144:636-9.

12 Checkley SA, Corn TH, Glass IB, Burton SW, Burke CA. The responsiveness of central alpha 2 adrenoceptors in depression. In: Deakin JFW, ed. The biology of depression. London: Gaskell, 1986:100-20.

13 Checkley SA. Neuroendocrine tests of monoamine function in man: a review of basic theory and its application to the study of depressive illness. Psychol Med 1980;10:35-53.

14 Lal S, Thavundayil J, Nair NPV, et al. Effect of sleep deprivation on dopamine receptor function in man. F Neural Transmission 1981;50:39-45.

15 Meltzer HY. Relevance of dopamine autoreceptors for psychiatry: preclinical and clinical studies. Schizophr Bull 1980;6:456-75.

16 Ettigi P, Lal S, Martin JB, Friesen HC. Effect of sex, oral contraceptives, and glucose loading on apomorphine-induced growth hormone secretion. $\mathcal{I}$ Clin Endocrinol Metab 1975;40:1094-8.

17 Wieck A, Hirst AD, Kumar R, Checkley SA, Campbell IC. Growth hormone secretion by human females in response to apomorphine challenge is markedly affected by menstrual cycle phase. Br f Clin Pharm 1989;27: $700-1 \mathrm{P}$

18 Gelato MC, Pescovitz OH, Cassorla F, Loriaux DL, Merriam GR. Doseresponse relationships for the effects of growth hormone-releasing factor$(1-44)-\mathrm{NH}_{2}$ in young adult men and women. $f$ Clin Endocrinol Metab 1984;59:197-201.

19 Ross RJM, Grossman A, Davies PSW, Savage MO, Besser GM. Stilboestrol pretreatment of children with short stature does not affect the growth hormone response to growth hormone-releasing hormone. Clin Endocrinol 1987;27:155-61

20 Demarest KT, Riegle GD, Moore KE. Long-term treatment with estradio induces reversible alterations in tuberoinfundibular dopaminergic neurons: a decreased responsiveness to prolactin. Neuroendocrinology 1984;39: $193-200$.

21 Van Hardtesveldt C, Joyce JN. Effects of estrogen on the basal ganglia. Neurosci and Biobehav Rev 1986;10:1-14.

22 Blum M, McEwen BS, Roberts JL. Transcriptional analysis of tyrosine hydroxylase gene expression in the tuberoinfundibular dopaminergic hydrox of the rat arcuate nucleus after estronen trealar dopaminergic neurons of the rat $1987 ; 262: 817-21$.
19.

23 Hamilton JA. The identity of postpartum psychiatric problems. In: Brockington IF, Kumar R, eds. Motherhood and mental illness. London: Academic ton IF, Kumar R,

(Accepted 28 fune 1991)
On August 29th Dr. Oliver Wendell Holmes attained the age of 82 , and we are sure that the whole medical profession on this side of the Atlantic will join with us in wishing many happy returns of the day to the graceful poet, the genial essayist, and the venerable ex-professor of anatomy, who has done more than any man living to prove that there is no necessary incompatibility between medicine and literature. This is a truth which in these days, when the literary element is being more and more thrust aside in the education of medical students, needs such a conspicuous example as that of Dr. Holmes to reinforce it, and all those medical men who have what may without offence be called a soul above their stethoscopes, and who are anxious not to see medicine lose the rank which it has so long held as one of the "learned" professions, should be deeply grateful to him for having shed the lustre of letters over our somewhat dismal science. Though he has long retired from active practice it is gratifying to learn that the Muses whom he has wooed so successfully have not been able to banish the love of medicine from his heart. He still continues to take the keenest interest in everything connected with the good repute and dignity of the profession which it may be hoped he will continue to adorn for many a long year. Not many months ago the editor of The Australasian Medical Gazette, having forwarded to Dr. Holmes copies of the evidence taken by the Select Committee of the Legislative Council of New South Wales, relative to the practice of medicine in that colony, received from him the following letter, which we need make no apology for giving in full:-

Boston, April 25th, 1891

MY DEAR SIR, - I thank you most cordially for the very important and interesting papers relating to quackery as it appears in your great colony.

Although it is a very long time since I have practised medicine, I retain my interest in all matters relating to the profession, and am glad to add these valuable documents to my library, for the present, but to go eventually with the rest of my medical books, which I gave some years ago to the Boston Medical Library. - Believe me, dear Sir, very truly and gratefully yours.

The Hon. John M. Creed, Sydney.

OLIVER WENDELl HOLMES.

(British Medical Fournal 1891;ii:655) 